\title{
Structure of Alpha-Gliadin Multigene and Construction of Efficient Hairpin RNAi Molecule against Gluten Enteropathy
}

\author{
Saeedeh Sadegzadeh*, Bahram Baghban Kohnehrouz \\ Department of Molecular Biology and Biotechnology, University of Tabriz, Tabriz, Iran \\ Email: *Saideh.sadegzadeh@gmail.com
}

How to cite this paper: Sadegzadeh, S. and Kohnehrouz, B.B. (2016) Structure of Alpha-Gliadin Multigene and Construction of Efficient Hairpin RNAi Molecule against Gluten Enteropathy. Advances in Bioscience and Biotechnology, 7, 531-538. http://dx.doi.org/10.4236/abb.2016.712047

Received: October 24, 2016

Accepted: December 4, 2016

Published: December 7, 2016

Copyright $\odot 2016$ by authors and Scientific Research Publishing Inc. This work is licensed under the Creative Commons Attribution International License (CC BY 4.0).

http://creativecommons.org/licenses/by/4.0/

\begin{abstract}
Celiac disease is known as gluten enteropathy, caused by damaging of small intestinal epithelium cells following gluten consumption. Gluten is classified in two families of glutenin and gliadin. Gliadin is divided into $\alpha, \gamma$ and $\omega$ groups. One of the most effective methods to rectify or minimize gene expression is RNAi technology. The present study has been conducted to the structure of $\alpha$-gliadin gene to produce proprietary RNAi cassette for silencing wheat $\alpha$-gliadin gene. So nucleotide sequence of $\alpha$-gliadin gene involved in design for PCR amplification by online primer-blast software. The amplification was extracted from agarose gel and ligated to pTG19 cloning vector. After cloning of the recombinant plasmid in E. coli, they were sequenced. Then they were used for construction of specific and efficient RNAi cassette. The produced vector by this strategy is considered as an effective step in developing genetically engineered gluten-less or low content gluten wheat.
\end{abstract}

\section{Keywords}

Cloning, Gluten, RNAi Technology, Vector, Wheat

\section{Introduction}

Celiac disease is also known as gluten enteropathy, and known as gluten intolerance disease. Celiac disease is an inherited disorder of the immune system that damages the lining of the small intestine, caused by gluten consumption and may impair the absorption of nutrients. People with celiac disease couldn't to endure a protein in wheat, barley, rye, and oats, called gluten. Today, the only way to treat celiac disease is gluten-free diets that all foods contain gluten are removed. Several studies have been conducted in this connection in order to produce gluten-free or very low gluten content product. 
Gluten is classified in two families of glutenins and gliadin [1]. Gliadins are divided to three structural classes of $\alpha, \gamma$ and $\omega$ groups [2]. However, $\alpha$-gliadin components are most important allergens [3]. Number of copies of hexaploid wheat $\alpha$-gliadin encoding gene is estimated at about 25 to 150 copies [1]. One of the effective methods for controlling allergen gens expression is RNAi technology (RNA interference) which used to extinguish or reduce gene expression. This method is now widely used for gen silencing in plants. RNAi is a conserved mechanism in a wide range of eukaryotic organisms except Saccharomyces cerevisiae [4]. RNAi inactivates gene expression in a sequencespecific manner [5]. In contrast, RNAi in plants is usually established by transformation with a construct that produces hairpin RNAs [6]. RNAi vector consists of an inverted repeat harbouring target sequences under the control of a strong promoter. The inverted repeat sequences are separated by a spacer fragment [5]. RNAi technology is effective and flexible in gene silencing in plants that led to the widespread use of this technology. The purpose of this research is producing proprietary RNAi cassette for wheat $\alpha$-gliadin. This plasmid is used for silencing specific genes and provides a means to reduce the gluten.

\section{Materials and Methods}

\subsection{Materials}

Triticum durum L. cv. Aria seeds provided from Karaj Plant Breeding department. Escherichia coli strain DH5 $\alpha$ (Invitrogen, USA) was used for cloning. The sequencing vector pTG19, Taq DNA polymerase and restriction enzymes were purchased Vivantis (USA) and Fermentas Corporation respectively. 5-bromo-4-chloro-3-indolyl- $\beta$-D-galactopyranoside (X-gal) and Isopropyl $\beta$-D-1-thiogalactopyranoside (IPTG) were obtained from Thermo Fisher Scientific Inc. (USA). DNA gel extraction and plasmid extraction kits were purchased from Bioneer Corporation (South Korea). Sequencing was conducted by BIONEER Co. (South Korea).

\subsection{Methods}

\subsubsection{Genomic DNA Extraction}

Seeds were cultivated under standard conditions in a green house. After growing in 2 3 leaves stage, leaf tissue genomic DNA was extracted by Cetyl Trimethyl Ammonium Bromide (CTAB). Extraction method as described by Saghai-Maroof [7]. Its quality and quantity were determined by $0.8 \%$ agarose gel electrophoresis.

\subsubsection{Bioinformatics' Analysis and First Step of Primer Design}

The sequences of $\alpha$-gliadin gene from Triticum spelta (GeneBank accession number AJ130948.1) were retrieved from the NCBI Gene Bank at the National Centre for Biotechnology Information (NCBI) (http://www.ncbi.nlm.nih.gov/BLAST/). In order to design specific primers, CLUSTALW program was used to carry out nucleotide sequence alignments. Forward Primer 5'ATCCATGGCCAATTTCACAGCAGCAGCA3' and reverse primer 5'ATCTGCAGAGGCTGTTGGAAGGAGACC3' were designed using Primer 
3 software at NCBI and their validity were confirmed by Oligo 7 software. The restriction enzyme sites, NcoI and EcoRI were added to 5'-ends of FP and RP primers.

\subsubsection{PCR Amplification and Cloning}

The total genomic DNA was used as a template for the amplification of $\alpha$-gliadin Using $\mathrm{RF}$ and RP primers. The reaction was carried out in a total volume 25 microliter $(\mu \mathrm{l})$. The amplification program was done as the primary denaturing using $94^{\circ} \mathrm{C}$ for $5 \mathrm{~min}$ ute (min), followed by 35 cycles of $94^{\circ} \mathrm{C}$ for 50 second (sec), $60^{\circ} \mathrm{C}$ for $45 \mathrm{sec}$, and $72^{\circ} \mathrm{C}$ for $2 \mathrm{~min}$, and a final extension step at $72^{\circ} \mathrm{C}$ for $7 \mathrm{~min}$. The amplified DNA products were separated by $0.8 \%$ agarose gel contains Red Safe and extracted using DNA gel extraction kit (Bioneer Co., Cat. No. 1/3035). The purified product were ligated into pTG19 vector (Takara Co.) and transformed into competent cells of $E$. coli DH5 $\alpha$ strain. Recombinant colonies were selected by white-blue test on Luria-Bertani (LB) medium containing antibiotic ampicillin $(100 \mu \mathrm{g} / \mathrm{ml})$, IPTG, $(100 \mu \mathrm{g} / \mathrm{ml})$ and X-gal $(1 \mathrm{mM})$ (Figure 1). The positive white colonies plasmid was extracted by Plasmid Extraction Kit (BIONNER Co.). Desired fragments were sequenced by the BIONEER Company (South Korea).

\subsubsection{The Second Step of Primer Design}

The obtained sequence was analysed by BLAST software. The specific new forward primer 5'ATCCATGGTGCAGCAACACAACATAGCG3' and reverse primer 5'ATGAATTCGAGGCTGTTGG AAGGAGACC3' designed to conduct for synthesis of target sequences from desired genes. NcoI and EcoRI restriction sites were added to 5'-ends of Forward and Reverse new primers.

\subsubsection{Create the RNAi Vector}

After verification, the ligation reaction was performed between two fragments to create final construction. The two-step procedure was carried out to making alpha gliadin RNAi cassette. Product I (481 bp fragment) followed by directional sub-cloning of its

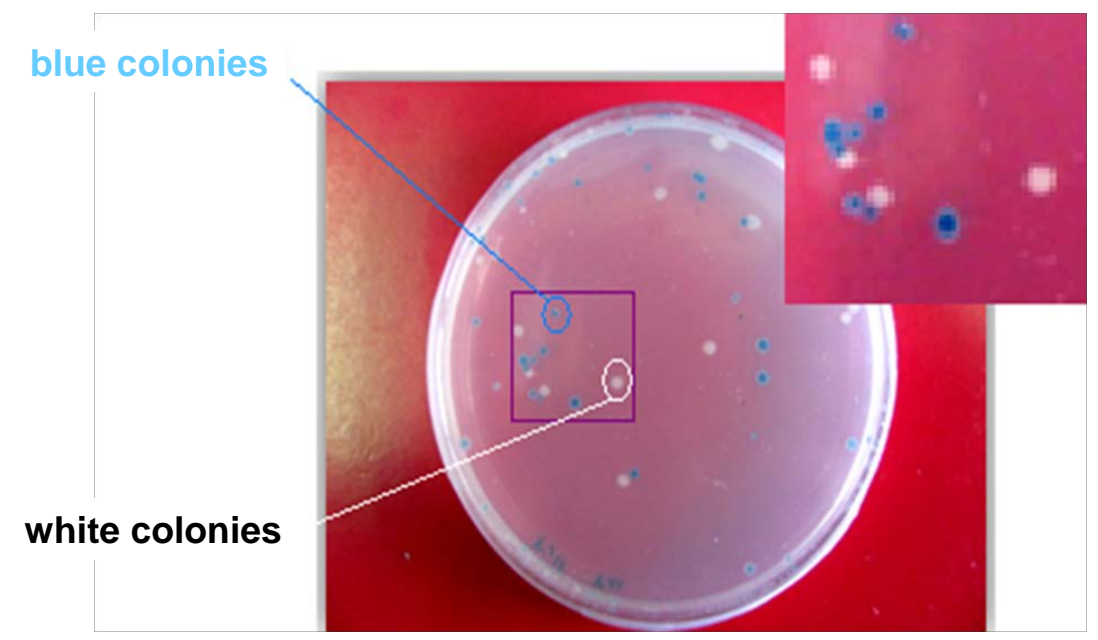

Figure 1. Bacterial colonies transformed with pTG19 vector. 
inverted orientation shorter fragment (product II, $331 \mathrm{bp}$ ). These two inverted regions separate by a 133 bp nucleotides as a spacer fragment (Figure 2(a)). Plasmid extraction was performed (using Bionner extraction kit) from liquid culture of white colonies after confirming by colony PCR method (Figure $3(\mathrm{~b})$ ). Purified plasmid DNA was sent to sequencing.

\section{Results and Discussion}

\subsection{Structural Feature of Designed RNAi}

Expression of this cassette by an appropriate promoter produce RNA molecule consisting of two inverted repeat fragments, leading to a hairpin structure. These two inverted

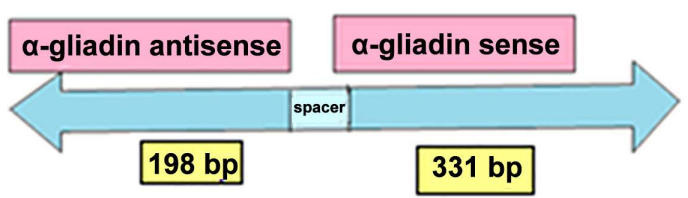

(a)

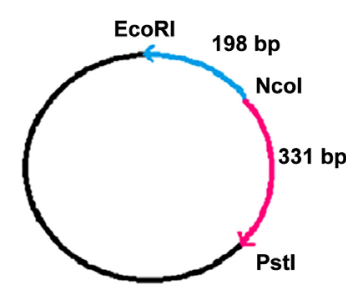

(b)

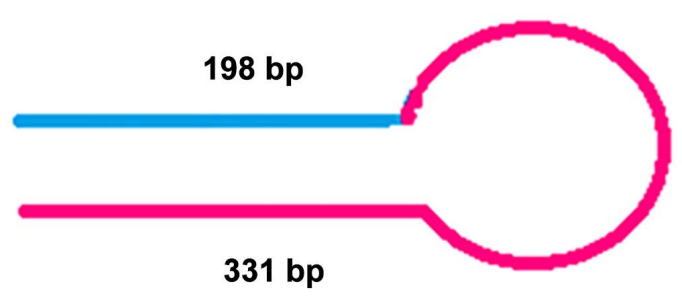

(c)

Figure 2. Fragment's position and RNAi schematic design. (a) Position and the length of sense and antisense amplified fragment, product (I) and product (II); (b) Position of fragments in the vector and restriction used enzymes; (c) Schematic structure of hairpin and the stem section.

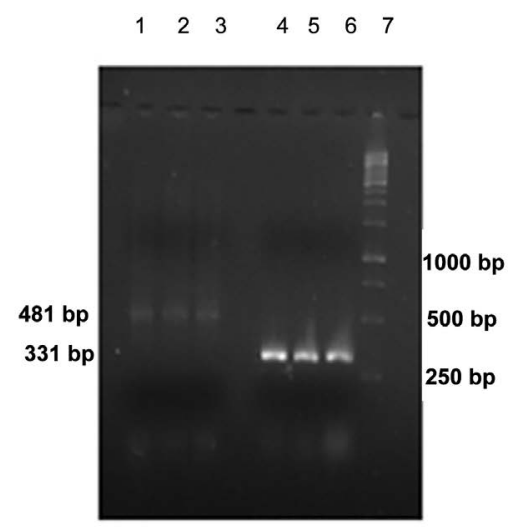

(a)

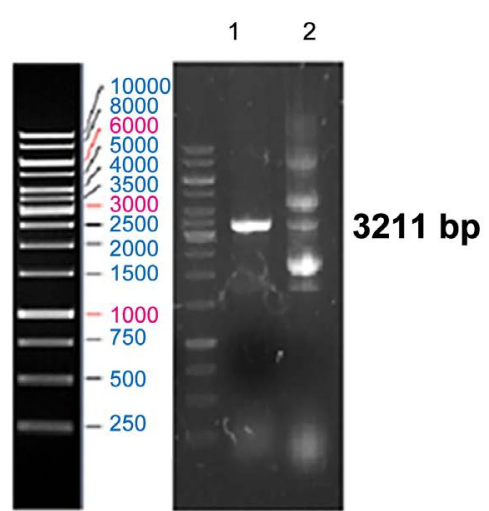

(b)

Figure 3. Identification of target fragments. (a) 1, 2, 3: PCR amplification of alpha gliadin $481 \mathrm{bp}$ fragment (produt 1), 4, 5, 6: PCR amplification of alpha gliadin $331 \mathrm{bp}$ fragment (product 2), 7: The DNA Marker; (b) Construction and identification of designed RNAi, 1: Recombinant plasmid, 2: Recombinant plasmid digestion with NcoI. 
regions separate by a $133 \mathrm{bp}$ nucleotides as a spacer fragment. The stem section of this construct contains about 198 bp out of 331 bp nucleotides as a double strand RNA. This region is a substrate for dicer and would produce small interfering RNA molecule to be anial to $\alpha$-gliadin mRNAs as well as a primer to double stranding mRNAs by RNA-dependent RNA polymerase (RDRP) enzyme (Figure 2(c)).

\subsection{Alpha Gliadin Gene Structure}

Alpha gliadin gene protein sequence had a common structure model: a short signal peptide with 20 amino acid residues followed by 5 distinct domains: a repetitive domain containing $\mathrm{N}$-terminal With 5 amino acid residues in the beginning a polyglutamine domain I, a unique domain I, a polyglutamine domain II and a unique domain II containing C-terminal in the end (Figure 4).

\subsection{Nucleotides and Amino Acids Sequence Comparison}

\subsubsection{Comparison and Sequencing Analysis of Amplified $\alpha$-Gliadin Fragment}

The Results of sequencing of Triticum durum L. cv. Aria seed $\alpha$-gliadin cloned fragment was compared with other 2547 alpha gliadin genes sequences from 19 different Triticum species reported in NCBI GenBank (Table 1). Nucleotides sequence comparison was based on multiple alignments by BLAST software. The nucleotide alignment results validated the sequence data of alpha gliadin with high homology identities more than $90 \%$. The results showed that Aria alpha gliadin gen had high similarity with other different species. Therefore the designed RNAi structure to alpha-gliadin gene silencing can be used in a wide variety of gramineae.

\subsubsection{Comparison of $\alpha$-Gliadin Gene Molecular Characterization}

Triticum durum L. cv. Aria seed $\alpha$-gliadin gene was used to detect amino acid sequences. Prediction of deduced amino acid sequences was carried out by COBALT software and compares ypi with 11 other alpha-gliadin amino acid sequences from 11 species reported in NCBI GenBank (Figure 5). Amino acid sequence comparison demonstrated that this cloned gene possessed tcal structural features of previously characterized $\alpha$-gliadin genes. The multiple alignment of deduced amino acid sequence showed that the Aria $\alpha$-gliadin gene had highly similar structure with other register

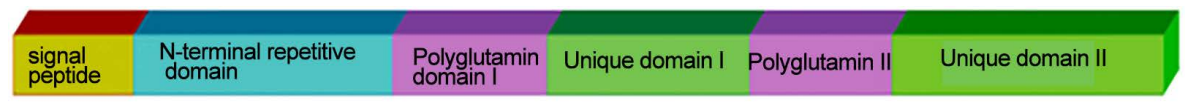

(a)

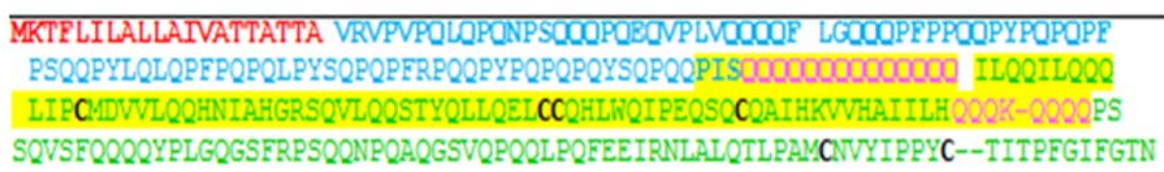

(b)

Figure 4. The structure of alpha gliadin gene. (a) Gene common structure; (b) Amino acid sequence and cloned fragment region (The region is highlighted in yellow). 
Table 1. Content of alpha gliadin genes in Triticum species, a comparative analysis and alignment result between Aria seed alpha gliadin gene and registered $\alpha$-gliadin gene sequences in Triticum species.

\begin{tabular}{|c|c|c|c|c|c|}
\hline \multicolumn{6}{|c|}{ Total alpha gliadin genes in Triticum species Total: 800} \\
\hline Name & \multicolumn{2}{|c|}{$\begin{array}{l}\text { Number of registered } \\
a \text {-gliadin genes }\end{array}$} & Name & \multicolumn{2}{|c|}{$\begin{array}{l}\text { Number of registered } \\
a \text {-gliadin genes }\end{array}$} \\
\hline Triticum aestivum & \multicolumn{2}{|c|}{333} & T. sphaerococum & \multicolumn{2}{|c|}{16} \\
\hline Triticum monocccm & \multicolumn{2}{|c|}{89} & T. turgidum sp. poleacolchicum & \multicolumn{2}{|c|}{9} \\
\hline Aegilops tauschii & \multicolumn{2}{|c|}{77} & T. turgidum subsp. turgidum & \multicolumn{2}{|c|}{6} \\
\hline Triticum urartu & \multicolumn{2}{|c|}{57} & T. polonicum & \multicolumn{2}{|c|}{5} \\
\hline Triticum dicoccoides & \multicolumn{2}{|c|}{57} & T. monococum subsp. armeniacum & \multicolumn{2}{|c|}{3} \\
\hline T. Compactum & \multicolumn{2}{|c|}{51} & T. spelta & \multicolumn{2}{|c|}{3} \\
\hline Aegilops speltoides & \multicolumn{2}{|c|}{37} & T. macha & \multicolumn{2}{|c|}{2} \\
\hline $\begin{array}{l}\text { Thinopyrum ponticum } \times \\
\text { T. aestivum }\end{array}$ & \multicolumn{2}{|c|}{27} & T. spelta var arduini & \multicolumn{2}{|c|}{1} \\
\hline Name & Total alignment & Number & Alignment result & Identic & Query cover \\
\hline \multicolumn{6}{|l|}{ T. aestivum } \\
\hline T. monococcum & 100 & $\begin{array}{c}96 \\
4\end{array}$ & $\begin{array}{l}\alpha \text {-gliadin isolate } \mathrm{A} 3 \text { avenin-like protein gene } \\
\text { complete cds }\end{array}$ & $\begin{array}{l}90 \% \\
75 \%\end{array}$ & $\begin{array}{l}95 \% \\
23 \%\end{array}$ \\
\hline Aegilops tauschii & 100 & 100 & $\alpha$-gliadin & $93 \%$ & $92 \%$ \\
\hline Aegilops speltoides & 55 & $\begin{array}{l}48 \\
3 \\
1 \\
1 \\
2\end{array}$ & $\begin{array}{l}\alpha \text {-gliadin Aegilops speltoides isolate A10 avenin } \\
\text { like protein } A \text {. peltoides mitochondrial DNA } \\
\text { complete cds } A \text {. speltoides } \text { isolate spE0061 } \\
\text { chloroplast complete gene } A \text {. speltoides }(\mathrm{Spa}) \\
\text { clone BAC }\end{array}$ & $\begin{array}{c}90 \% \\
73 \% \\
86 \% \\
100 \% \\
94 \%\end{array}$ & $\begin{array}{c}95 \% \\
27 \% \\
10 \% \\
4 \% \\
5 \%\end{array}$ \\
\hline T. urartu & 66 & $\begin{array}{c}59 \\
6 \\
1\end{array}$ & $\begin{array}{l}\alpha \text {-gliadin } \\
\text { T. urartu clone BAC complete cds } \\
\text { T. urartu chloroplast complete sequence }\end{array}$ & $\begin{array}{l}92 \% \\
94 \% \\
86 \%\end{array}$ & $\begin{array}{c}95 \% \\
5 \% \\
6 \%\end{array}$ \\
\hline T. dicoccoides & 60 & $\begin{array}{c}58 \\
2\end{array}$ & $\begin{array}{l}\alpha \text {-gliadin } T \text {. dicoccoides clone BAC genomic } \\
\text { sequence }\end{array}$ & $\begin{array}{l}93 \% \\
90 \%\end{array}$ & $\begin{array}{l}95 \% \\
6 \%\end{array}$ \\
\hline T. compactum & 41 & 41 & $\alpha$-gliadin & $97 \%$ & $77 \%$ \\
\hline T. turgidum subsp. durum & 38 & $\begin{array}{c}25 \\
6 \\
7\end{array}$ & $\begin{array}{l}\alpha \text {-gliadin } T \text {. turgidum isolate A avenin like protein } \\
\text { psedogen complete sequence } \\
\text { T. turgidum clone BAC }\end{array}$ & $\begin{array}{l}91 \% \\
73 \% \\
90 \%\end{array}$ & $\begin{array}{c}95 \% \\
27 \% \\
5 \%\end{array}$ \\
\hline $\begin{array}{l}\text { T. turgidum subsp. } \\
\text { poleacolchicum }\end{array}$ & 14 & $\begin{array}{l}9 \\
5\end{array}$ & $\begin{array}{l}\alpha \text {-gliadin } T \text {. poleacolchicum Ppd-B1 gene for } \\
\text { Pseudo response regulator }\end{array}$ & $\begin{array}{r}92 \% \\
100 \%\end{array}$ & $\begin{array}{c}95 \% \\
3 \%\end{array}$ \\
\hline T. turgidum subsp. turgidum & 6 & 6 & $\alpha$-gliadin & $86 \%$ & $13 \%$ \\
\hline T.polonicum & 5 & 5 & $\alpha$-gliadin & $91 \%$ & $95 \%$ \\
\hline $\begin{array}{l}\text { T. timophevii subsp. } \\
\text { armeniacum }\end{array}$ & 2 & 2 & $\alpha$-gliadin & $90 \%$ & $95 \%$ \\
\hline T. aestivum subsp. macha & 3 & 3 & $\alpha$-gliadin & $86 \%$ & $93 \%$ \\
\hline T. sephaerocum & 19 & $\begin{array}{c}16 \\
2 \\
1\end{array}$ & $\begin{array}{l}\alpha \text {-gliadin spelt factor protein MADS-box } \\
\text { transcription factor (MADS) gene }\end{array}$ & $\begin{array}{r}91 \% \\
93 \% \\
100 \%\end{array}$ & $\begin{array}{c}95 \% \\
4 \% \\
3 \%\end{array}$ \\
\hline T. spelta & 3 & 3 & $\alpha$-gliadin & $93 \%$ & $93 \%$ \\
\hline T. spelta var arduini & 1 & 1 & $\alpha$-gliadin & $93 \%$ & $92 \%$ \\
\hline & & 1 & $\alpha$-gliadin & $90 \%$ & $91 \%$ \\
\hline T. zhakovski & 3 & 1 & LMW & $100 \%$ & $10 \%$ \\
\hline & & 1 & (Matk) gene & $93 \%$ & $4 \%$ \\
\hline
\end{tabular}




\begin{tabular}{|c|c|c|}
\hline \multicolumn{2}{|r|}{ Accession } & \\
\hline$\sqrt{v}$ & |cl|10001 & gi|3928509|emb|CAA10257.1| alpha-gliadin, partial [Jriticum spelta var. arduini] \\
\hline$\sqrt{2}$ & $|c| \mid 10002$ & gi|421932434|gb|AFX69595.1| alpha-gliadin [Aegilons tauschii] \\
\hline$\sqrt{2}$ & Ic||10003 & gi|627766398|gb|AHY37809.1| alpha-gliadin [Aegilons speltoides] \\
\hline$\sqrt{v}$ & $|c| \mid 10004$ & gi|205321004|gb|ACI03051.1| alpha gliadin Gli-2 [Triticum timopheevii subsp. armeniacum] \\
\hline$\sqrt{2}$ & $|c| \mid 10005$ & gi|393395440|gb|AFN08653.1| alpha-gliadin protein [Triticum dicoccoides] \\
\hline$\sqrt{2}$ & $|c| \mid 10006$ & gi|82880023|gb|ABB92633.1| alpha-gliadin protein [Triticum turgidum subsp. durum] \\
\hline$\sqrt{v}$ & Ic||10007 & gi|421932398|gb|AFX69577.1| alpha-gliadin [Triticum menececcum] \\
\hline$\sqrt{2}$ & $|c| \mid 10008$ & gi|282721192|gb|ADA83696.1| alpha-gliadin [Triticum polonicum] \\
\hline$\sqrt{2}$ & $|c| \mid 10009$ & gi|146762356|gb|ABQ45317.1| alpha-gliadin Gli-Ts1 [Triticum sphaerococcum] \\
\hline$\sqrt{2}$ & $|c| \mid 10010$ & gi|380875475|gb|AFF27498.1| alpha gliadin [Triticum urartu] \\
\hline$\sqrt{\square}$ & $|c| \mid 10011$ & gi|166406979|gb|ABY87439.1| alpha-gliadin [Triticum turgidum subsp. paleocolchicum] \\
\hline
\end{tabular}

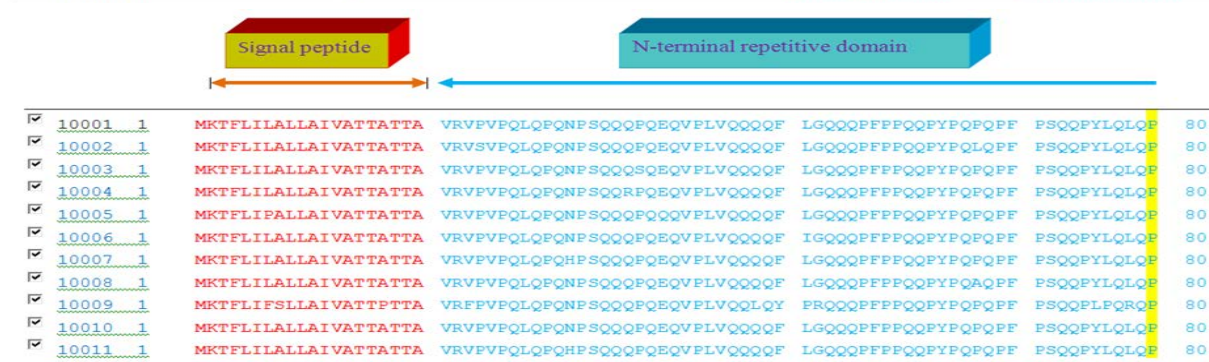

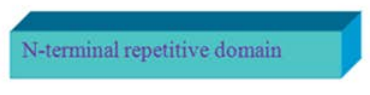

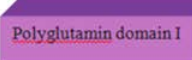

Unique domain I

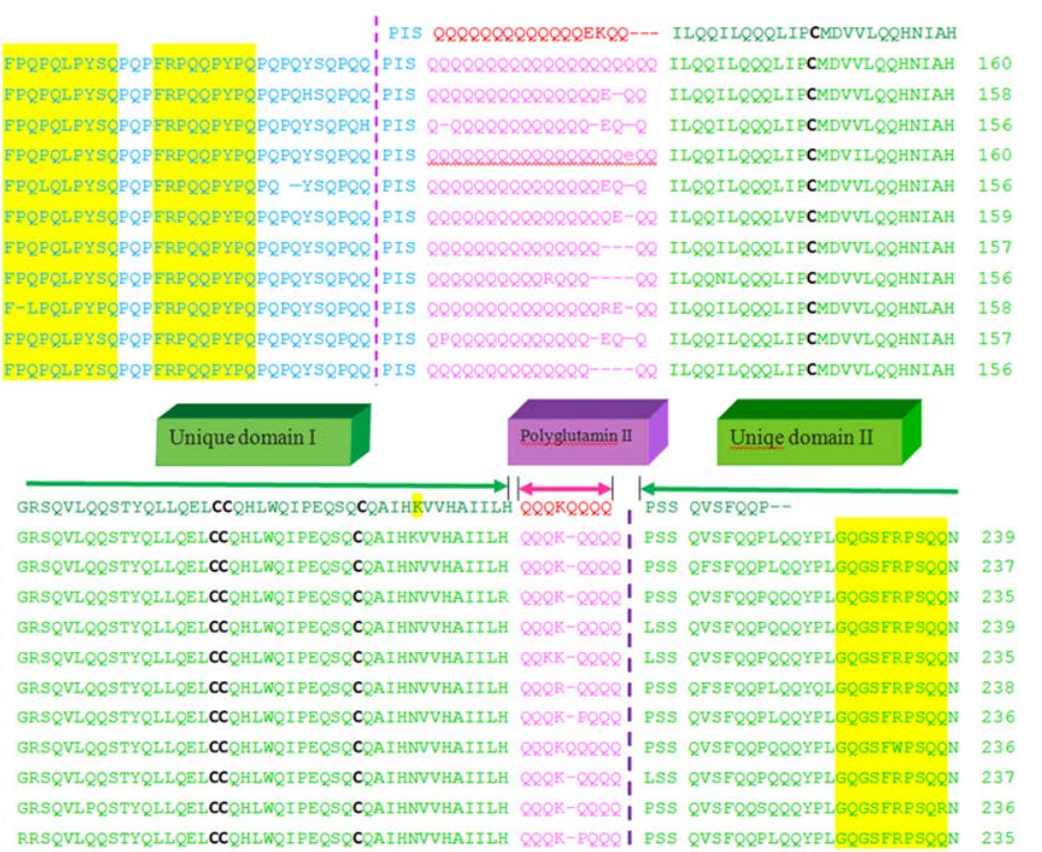

Figure 5. Representative protein accetion numbers and multiple alignment of the deduced amino acid sequences of Aria alpha-gliadin genes with amino acid sequences of 11 different Triticum species (Red region: signal Peptide, blue region: $\mathrm{N}$-terminal repetitive domain, violet regions: poly glutamine domain I and II, gr).

$\alpha$-gliadin genes in the GenBank. The produced results and comparison between the cloned sequence and other species, confirmed that the main allergen region in alpha 
gliadin gene had been detected properly and selected for design a specific and efficient hairpin RNAi molecule against gluten enteropathy.

\section{Discussion}

Alpha-gliadin is the most abundant wheat seed protein that has basic and principle role in the sensitivity of patients with Celiac disease. RNAi technologies make it possible to effectively down-regulate the target mRNA of alpha-gliadin multigenes from wheat, which causes celiac disease symptoms in genetically predisposed individuals. Thus, we have designed and developed a specific and an efficient RNAi cassette as a critical step for targeting wheat alpha-gliadin. According to our results, it appears that with respect to the selected sequence and final design of its structure, it is an efficient and suitable one for controlling the allergen genes and in particular alpha-gliadin gene family in all groups. This would be in wheat and in all variety of gramineae to create an effective silencing gene.

\section{Acknowledgements}

The authors are grateful for support of this work by the University of Tabriz.

\section{References}

[1] Anderson, O.D. and Greene, F.C. (1997) The Alpha-Gliadin Gene Family. II. DNA and Protein Sequence Variation, Subfamily Structure, and Origins of Pseudo Genes. Theoretical Applied Genetics, 95, 59-65. https://doi.org/10.1007/s001220050532

[2] Dziuba, M., Nałęcz, D., Szerszunowicz, I. and Waga, J. (2014) Proteomic Analysis of Wheat $\alpha / \mathrm{A}$ - and $\beta$-Gliadins. Czech Journal of Food Sciences, 32, 437-442.

[3] Arentz-Hansen, H., Korner, R. and Molberg, Q. (2002) Celiac Lesion T Cells Recognize Epitope That Cluster in Regions of Gliadins Rich in Proline Residues. Gastroenterology, 123, 803-809. https://doi.org/10.1053/gast.2002.35381

[4] Grewal, S.I.S. and Moazed, D. (2003) Heterochromatin and Epigenetic Control of Gene Expression. Science, 301, 798-802. https://doi.org/10.1126/science.1086887

[5] Hirai, S. and Kodama, H. (2008) RNAi Vectors for Manipulation of Gene Expression in Higher Plants. The Open Plant Science Journal, 2, 21-30.

[6] Kato, A., Endo, M., Kato, H. and Saito, T. (2005) The Antisense Promoter of AtRE1, a Retrotransposon in Arabidopsis thaliana, Is Activated in Pollens and Calluses. Plant Science, 168, 981-986. https://doi.org/10.1016/j.plantsci.2004.11.010

[7] Saghai-Maroof, M.A., Soliman, K., Jorgensen, R.A. and Allard, R.W. (1984) Ribosomal DNA Spacer Length Polymorphisms in Barley: Mendelian Inheritance, Chromosomal Location, and Population Dynamics. Proceedings of the National Academy of Sciences of the United States of America, 81, 8014-8018. https://doi.org/10.1073/pnas.81.24.8014 
Submit or recommend next manuscript to SCIRP and we will provide best service for you:

Accepting pre-submission inquiries through Email, Facebook, LinkedIn, Twitter, etc. A wide selection of journals (inclusive of 9 subjects, more than 200 journals)

Providing 24-hour high-quality service

User-friendly online submission system

Fair and swift peer-review system

Efficient typesetting and proofreading procedure

Display of the result of downloads and visits, as well as the number of cited articles

Maximum dissemination of your research work

Submit your manuscript at: http://papersubmission.scirp.org/

Or contact abb@scirp.org 